\title{
THE EFFECT OF ULTRASOUND ON THE RHEOLOGICAL PROPERTIES OF APPLE JUICE
}

\author{
Kamil WILCZYŃSKI, Zbigniew KOBUS, Rafał NADULSKI, \\ Marian PANASIEWICZ, Andrzej KUSZ \\ University of Life Sciences in Lublin, POLAND \\ E-mail of corresponding author: kamilwilczynski100@wp.pl
}

Keywords: ultrasound, rheological properties, apple juice, energy consumption

\begin{abstract}
In this paper, the effect of ultrasonic treatment on the rheological properties of apple juice (Idared variety) was studied. The juice was treated with ultrasonic waves for 5 and 10 minutes relative to the untreated sample. The tests were conducted using rotational viscometer at shear rates ranging from 40 to $140 \mathrm{~s}^{-1}$ at constant temperature of $20^{\circ} \mathrm{C}$. There was no influence of ultrasonic treatment on the rheological character of apple juice. The rheological behaviour of untreated apple juice had the characteristics of non-Newtonian fluids. The value of the flow index was less than 1, indicating its pseudoplastic character. Because the ultrasonic treatment doesn't change the structural properties it can be used for mild preservation of apple juice. This technology of juice processing allows to reduce the energy consumption, what contributes to the rational management of energy resources.
\end{abstract}

\section{INTRODUCTION}

The scientists and government organizations around the world are working to promote and implement alternative agricultural practices that maximize the benefits of sustainable agriculture. These actions are accompanied by attention to reduce energy consumption during processing, transport and production of goods with limited or no waste (Tilman et al., 2002).

Therefore, solutions are being sought based on the available technologies, which aim to improve economic growth, while minimizing the impact on the natural environment (Altieri 1995; Urbaniec et al., 2016).

The alternative may be new ultrasound-based technologies, which due to the acceleration of many processes (Kobus 2008; Cai et al., 2016) and reduction of energy consumption allows them to obtain higher quality products, and reducing or eliminating adverse effects on the environment (Cintas 2016; Draye and Kardos 2016).

Currently, research is performing on the use of ultrasound energy for gentle preservation of fruit juices (Rojas et al., 2016). The sound waves can inactivate enzymes and microorganisms by denaturing or breaking down of protein structures (Kwiatkowska et al., 2011). Ultrasonic treatment can have a substantial impact on the rheological properties of the liquid (Bot et al., 2017). Rheological characteristics are important in transport, storage and structural changes in the liquid (Kobus 2015).

The aim of the study was to investigate the effect of ultrasound on the rheological properties of apple juice.

\section{MATERIAL AND METHODS}

The research material was apple juice from the Idared variety. The juice was obtained after crushing on a laboratory basket press. To test the juice was filtered to remove pulp particles.

The process of ultrasonic treatment was carried out using an ultrasonic generator Sonic VC 750 with power of $750 \mathrm{~W}$ and the head having a diameter of $19.05 \mathrm{~mm}$. A sample of 
$60 \mathrm{ml}$ of apple juice was treated for 5 and $10 \mathrm{~min}$ at ultrasonic intensity of $1.16 \mathrm{~W} \cdot \mathrm{cm}^{-3}$. Rheological properties were measured using Brookfield viscometer (Brookfield Engineering Laboratories: model LVDV-II + PRO). A sample of $16 \mathrm{ml}$ of apple juice was used in ULA-baker for all experiments. The tests were conducted using rotational viscometer at shear rates ranging from 40 to $140 \mathrm{~s}^{-1}$. By using a water bath (Brookfield TC-502P) the temperature was kept constant value on $20^{\circ} \mathrm{C}$. The viscosity curves and flow curves were determined on the basis of the computer software (Rheocalc 3.1).

In addition, changes in the extract content and temperatures after wave treatment were measured. All experiments were carried out in three replications. The relationship between shear stress and shear rate was determined using the Ostwald-de Waele model described by the following equation:

where:

$$
\tau=\mathrm{k} \cdot \gamma^{\mathrm{n}}
$$

$\tau$ - shear stress $(\mathrm{Pa})$,

$\mathrm{k}-$ consistency coefficient $\left(\mathrm{Pa} \cdot \mathrm{s}^{\mathrm{n}}\right)$,

$\gamma$ - shear rate $\left(\mathrm{s}^{-1}\right)$,

$\mathrm{n}-$ flow behaviour index (-).

\section{RESULTS}

Figure 1 shows temperature changes of apple juice during ultrasonic treatment depending on the treatment time. In both cases the temperature increases gradually to reach respectively a value of $75^{\circ} \mathrm{C}$ after $5 \mathrm{~min}$ and $85^{\circ} \mathrm{C}$ after $10 \mathrm{~min}$.

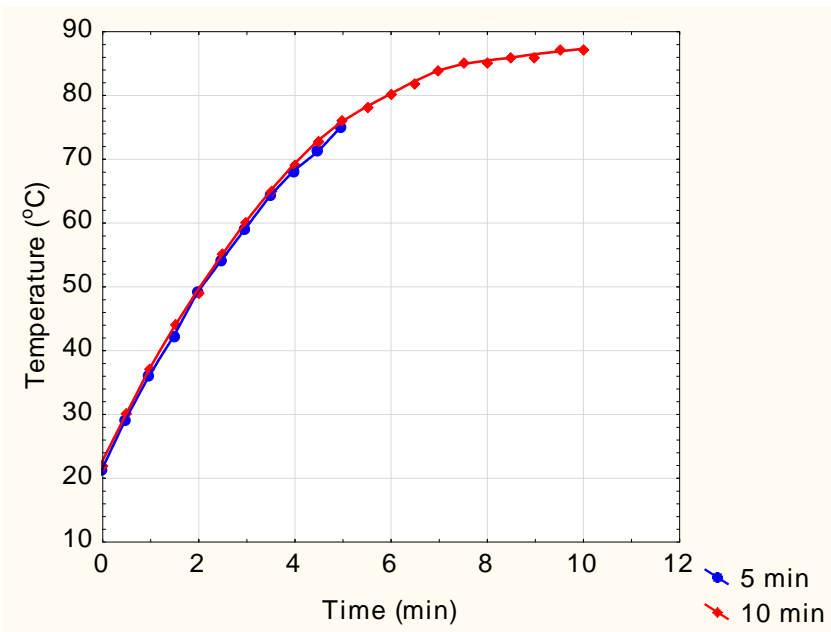

Fig. 1. The influence of ultrasound on the change in temperature apple juice

Table 1 shows the content of the extract for the raw juice and after the ultrasonic treatment. It showed an increase in sugar content, with increasing treatment time. But this effect may be caused by evaporation of some amount of water from the sample due to the increase in temperature.

Table 1. The content of apple juice extract before and after ultrasonic treatment

\begin{tabular}{|l|c|}
\hline Kind of treatment & Extract content $\left({ }^{\mathbf{0}} \mathbf{B x}\right)$ \\
\hline Raw juice & $7.950 \pm 0.05$ \\
5 min US treatment & $8.125 \pm 0.43$ \\
10 min US treatment & $8.725 \pm 0.43$ \\
\hline
\end{tabular}


In Fig. 2 and 3 were shown flow and viscosity curves for three samples of tested juices.

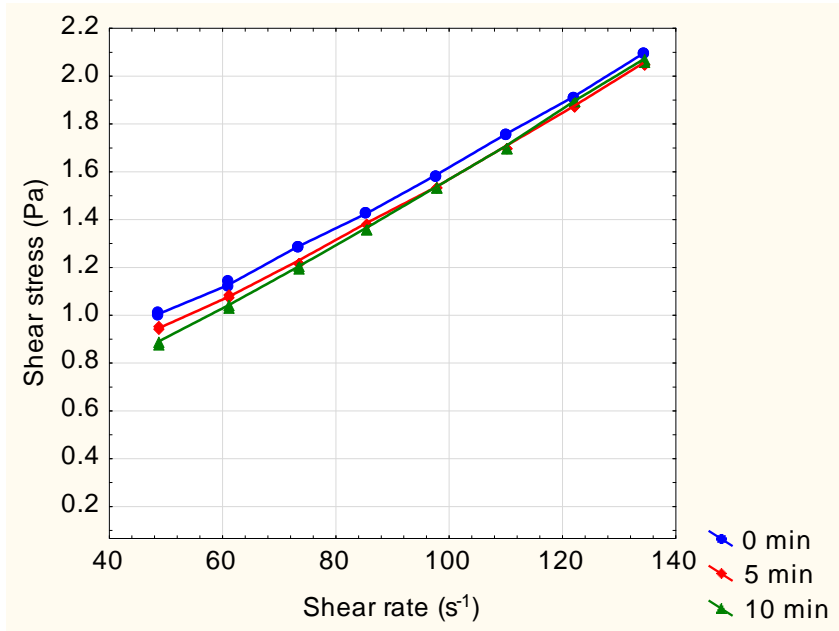

Fig. 2. Flow curves for apple juice depending on the applied treatment

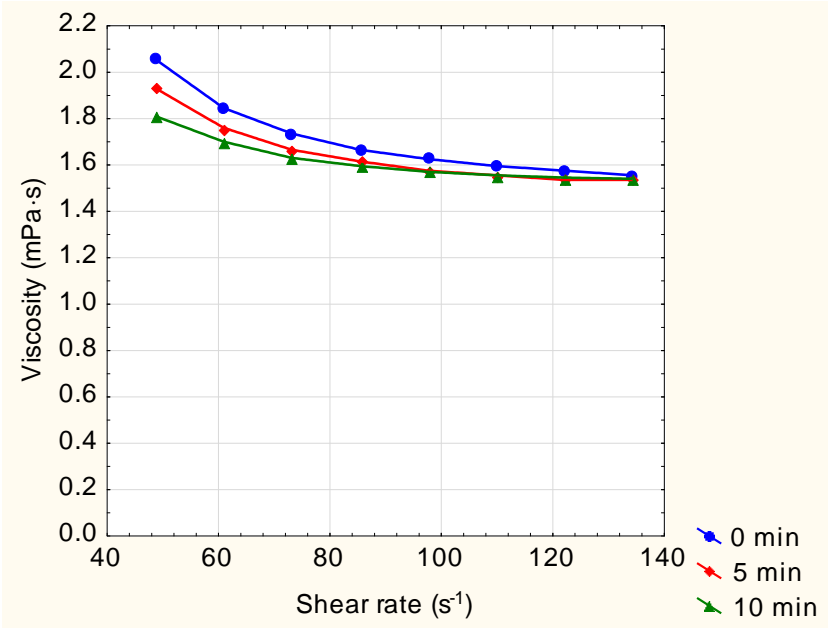

Fig. 3. Viscosity curves according to apple juice depending on the applied treatment

On the basis of the shape of the flow and viscosity curves, it can be concluded that the tested juice exhibits non-Newtonian behaviour.

In table 2 were presented values of consistency coefficient and flow behaviour index for the tested juices. Due to the fact that juices exhibited non-Newtonian behaviour Ostwaldde Waele model was applied to calculate its rheological properties.

Table 2. The rheological properties of the Ostwald-de Waele model for juice, depending on the treatment

\begin{tabular}{|l|c|c|}
\hline Kind of treatment & Consistency coefficient $\left(\mathrm{Pa} \cdot \mathrm{s}^{\mathrm{n}}\right)$ & Flow behaviour index (-) \\
\hline Raw juice & $0.04960^{\mathrm{a}}$ & $0.7589^{\mathrm{b}}$ \\
5 min US treatment & $0.05188^{\mathrm{a}}$ & $0.7547^{\mathrm{b}}$ \\
10 min US treatment & $0.04569^{\mathrm{a}}$ & $0.8177^{\mathrm{b}}$ \\
\hline
\end{tabular}

$a, b$ the same letter for each parameter in column are not significantly different at a confidence of $95 \%$ (Tukey's test, $p<0.05$ )

The value of the flow index are different from the 1 which indicating the non-Newtonian liquid character. All the values of flow behaviour index are below 1 supporting the pseudoplastic behaviour of tested juices. Statistical analysis showed no significant effect of ultrasonic treatment on the consistency coefficient and flow index. 


\section{CONCLUSIONS}

Research on the influence of ultrasonic treatment during 5 and $10 \mathrm{~min}$ on rheological properties of apple juice versus control (raw juice) was performed. Untreated juice exhibited non-Newtonian liquid properties. The ultrasonic treatment didn't change rheological behaviour of apple juice. There was also no statistically significant effect of ultrasonic processing on the values of consistency coefficient and the flow index of the tested apple juice.

It can be concluded that sonification at this level of intensity doesn't effect on changes in structural properties of juice. The results of the study indicate that the applied ultrasonic intensity can be used to gentle apple juice preservation. This mild way of juice processing allows to reduce the energy consumption, what is important for the sustainable use of energy sources in the food and agriculture sector.

\section{REFERENCES}

Altieri M.A. (1995) Agroecology: the science of sustainable agriculture, Westview Press, Boulder, CO, USA, $433 \mathrm{p}$.

Bot, F., Calligaris, S., Cortella, G., Nocera, F., Peressini, D., Anese, M., (2017). Effect of high pressure homogenization and high power ultrasound on some physical properties of tomato juices with different concentration levels. Journal of Food Engineering, 213, 10-17.

Cai, Z., Qu, Z., Lan, Y., Zhao, S., Ma, X., Wan, Q., Jing, P., Li, P., (2016). Conventional, ultrasoundassisted, and accelerated-solvent extractions of anthocyanins from purple sweet potatoes. Food Chemistry, 197, 266-272.

Cintas, P., (2016). Ultrasound and green chemistry - Further comments. Ultrasonics Sonochemistry, 28, 257-258.

Draye, M., Kardos, N., (2016). Advances in Green Organic Sonochemistry. Topics in Current Chemistry, $374(5), 74$.

Kobus, Z., (2008). Dry matter extraction from valerian roots (Valeriana officinalis L.) with the help of pulsed acoustic field. International Agrophysics, 22, 133-137.

Kobus, Z., Nadulski, R., Guz, T., Mazur, J., Panasiewicz, M., Zawiślak, K., (2015). Effect of Pasteurization on Rheological Properties of White Carrot Juice. Agriculture and Agricultural Science Procedia, 7, 99-102.

Kwiatkowska, B., Bennett, J., Akunna, J., Walker, G.M., Bremner, D.H., (2011). Stimulation of bioprocesses by ultrasound. Biotechnol Adv., 29 (6), 768-80.

Rojas, M.L., Leite, T.S., Cristianini, M., Alvim, I.D., Augusto P.E.D., (2016). Peach juice processed by the ultrasound technology: Changes in its microstructure improve its physical properties and stability. Food Research International, 82, 22-33.

Tilman, D., Cassman, K.G., Matson, P.A., Naylor, R., Polasky, S., (2002). Agricultural sustainability and intensive production practices. Nature, 418 (6898), 671-677.

Urbaniec, K., Mikulcic, H., Duic, N., Lozano, R., (2016). SDEWES 2014 - Sustainable Development of Energy, Water and Environment Systems. Journal of Cleaner Production, 130, 1-11. 